\title{
Evaluation Biochemical Parameter in Breast Cancer
}

\section{Banger MG1 ${ }^{1}$, Bhise $\mathrm{M}^{2 *}$ and Khillare $\mathrm{S}^{2}$}

${ }^{1}$ Department of biochemistry, Grant government medical college \& Sir JJ group of hospitals, India

${ }^{2}$ Department of biochemistry, Lokmanya Tilak Municipal Medical College and Sion Hospital, India

*Corresponding author: Meghatai Bhise, Assistant Professor, Department of biochemistry, Lokmanya Tilak Municipal Medical College and Sion Hospital, Mumbai, India, Tel: 8451063965; Email: mkhandode@gmail.com

\section{Research Article}

Volume 4 Issue 3

Received Date: May 31, 2019

Published Date: June 21, 2019
DOI: $10.23880 / \mathrm{ijbp}-16000165$

\section{Abstract}

Objective: To study and compare biochemical parameter such as serum Lipid profile and alkaline phosphate in patients of carcinoma of breast with healthy normal controls.

Methods: A cross sectional study was conducted in the Department of Biochemistry government medical college Nagpur with cooperation from surgery Department of the institute during period of May 2015 to October 2016. The study was approved by institutional Ethics Committee for research work. A total of 200 subjects were enrolled in this study, who were further divided into two groups of group A 100 subjects each between 25-75 years of age as histopathologically confirmed breast cancer cases and group B 100 subject of age, weight matched controls. Data was analyzed using unpaired $t$ test. $\mathrm{P}<0.05$ was considered to be statistically significant and $\mathrm{P}<0.001$ was taken as statistically highly significant

Results: Breast cancer of serum cholesterol, Serum triglycerides, serum HDL, serum LDL, serum VLDL level and serum Alkaline phosphatase $165.96 \pm 25.9 \mathrm{mg} / \mathrm{dl}, 115.54 \pm 27.73 \mathrm{mg} / \mathrm{dl}, 52.43 \pm 6.45 \mathrm{mg} / \mathrm{dl}, 90.49 \pm 24.53 \mathrm{mg} / \mathrm{dl}, 23.04+5.55 \mathrm{mg} / \mathrm{dl}$ $73.16 \pm 10.2 \mathrm{IU} / \mathrm{L}$, as compared to mean of normal women $197.14 \pm 36.14 \mathrm{mg} / \mathrm{dl} 120.70 \pm 29.66 \mathrm{mg} / \mathrm{dl} 51.03 \pm 4.8 \mathrm{mg} / \mathrm{dl}$ $121.97 \pm 36.39 \mathrm{mg} / \mathrm{dl} 24.14+5.93 \mathrm{mg} / \mathrm{dl} 74.28 \pm 10.6 \mathrm{IU} / \mathrm{L}$ respectively

Conclusion: The study showed that breast cancer patients had significantly higher levels of total cholesterol \& LDLcholesterol while insignificant association was found in levels of HDL-cholesterol, VLDL-cholesterol \& triglycerides between cases \& controls. Serum ALP level didn't differ significantly.

Keywords: Breast Cancer; Lipid Profile; Alkaline Phosphate 


\section{International Journal of Biochemistry \& Physiology}

\section{Introduction}

Carcinoma breast is commonest cancer in urban and rural females in India [1,2]. With over one million new cases in the world each year, breast cancer is the commonest malignancy in women $(23 \%$ of all the cancers), ranking second overall when both sexes are considered together [3]. Proteins and lipids form specialized clusters in blood called as lipoproteins, which all tangled up together to carry lipids in our blood. These form fundamental component of cell membrane and play a vital role in cell growth and division and are also required for maintaining the cell integrity of normal and malignant tissues. Energy in the body is mainly stored as triglycerides (TGs). TGs and cholesterol are first packed into lipoproteins and transported in plasma and later are taken up and degraded by cells for the cellular functions.

Alkaline phosphatase is a hydrolase enzyme responsible for removing phosphate group from many types of molecules including nucleotides, proteins, and alkaloids.

\section{Materials and Methods}

A cross sectional study was conducted in the Department of Biochemistry of medical college with cooperation from surgery Department of the institute during period of May 2015 to October 2016. The study was approved by institutional Ethics Committee for research work. A total of 200 subjects were enrolled in this study, who were further divided into two groups of 100 subjects each between 25-75 years of age as histopathologically confirmed breast cancer cases and age, weight matched controls. Data was analyzed using unpaired $t$ test. $\mathrm{P}<0.05$ was considered to be statistically significant and $\mathrm{P}<0.001$ was taken as statistically highly significant.

\section{Results}

Total Cholesterol: The mean of total cholesterol in controls \& cases were $165.96 \pm 25.9 \mathrm{mg} / \mathrm{dl}, 197.14 \pm 36.14$ $\mathrm{mg} / \mathrm{dl}$ respectively. There was significant difference in total Cholesterol concentrations between patient and control $(\mathrm{p}>0.0001)$.

LDL-cholesterol: The mean of LDL-cholesterol in controls \& cases were $90.49 \pm 24.53 \mathrm{mg} / \mathrm{dl}$ and $121.97 \pm 36.39 \mathrm{mg} / \mathrm{dl}$ respectively. There was significant difference in LDL-Cholesterol concentrations between patient and control $(\mathrm{p}>0.0001)$.

HDL cholesterol: The mean of HDL-cholesterol in controls \& cases were $52.43 \pm 6.45 \mathrm{mg} / \mathrm{dl}, 51.03 \pm 4.89$ $\mathrm{mg} / \mathrm{dl}$ respectively. There was no significant difference in HDL between patient and control ( $p>0.05)$.

Triglycerides: The mean of triglycerides in controls \& cases were $115.54 \pm 27.73 \mathrm{mg} / \mathrm{dl}, 120.70 \pm 29.66 \mathrm{mg} / \mathrm{dl}$ respectively. There was no significant difference in Triglycerides between patient and control $(\mathrm{p}>0.05)$.

VLDL- cholesterol: The mean of VLDL-cholesterol in controls \& cases were $23.04+5.55$ \& 24.14+5.93 respectively. There was no significant difference in VLDLcholesterol between patient and control ( $p>0.05)$.

ALP: The mean of serum ALP in controls \& cases were $73.16 \pm 10.2 \mathrm{IU} / \mathrm{L}, 74.28 \pm 10.6 \mathrm{IU} / \mathrm{L}$ respectively. There was no significant difference in ALP between patient and control.

\begin{tabular}{|c|c|c|c|}
\hline & Controls & Cases & \multirow{2}{*}{ P value } \\
\cline { 2 - 3 } & $(\mathrm{n}=100)$ & $(\mathrm{n}=100)$ & \\
\hline Total cholesterol $(\mathrm{mg} / \mathrm{dl})$ & $165.96 \pm 25.9$ & $197.14+36.14$ & 0.0000001 \\
\hline HDL-cholesterol $(\mathrm{mg} / \mathrm{dl})$ & $52.43 \pm 6.45$ & $51.03+4.89$ & 0.08 \\
\hline LDL-cholesterol $(\mathrm{mg} / \mathrm{dl})$ & $90.49 \pm 24.53$ & $121.97+36.39$ & 0.0000001 \\
\hline VLDL-cholesterol $(\mathrm{mg} / \mathrm{dl})$ & $23.04 \pm 5.55$ & $24.14+5.93$ & 0.177 \\
\hline Triglycerides $(\mathrm{mg} / \mathrm{dl})$ & $115.54 \pm 27.73$ & $120.70+29.66$ & 0.2 \\
\hline ALP $(\mathrm{IU} / \mathrm{L})$ & $73.16 \pm 10.2$ & $74.28+10.60$ & 0.44 \\
\hline
\end{tabular}

Table 1: Comparison of total cholesterol, HDL- cholesterol, LDL- cholesterol, VLDL cholesterol, Triglycerides, Alkaline phosphate in study groups. 


\section{International Journal of Biochemistry \& Physiology}

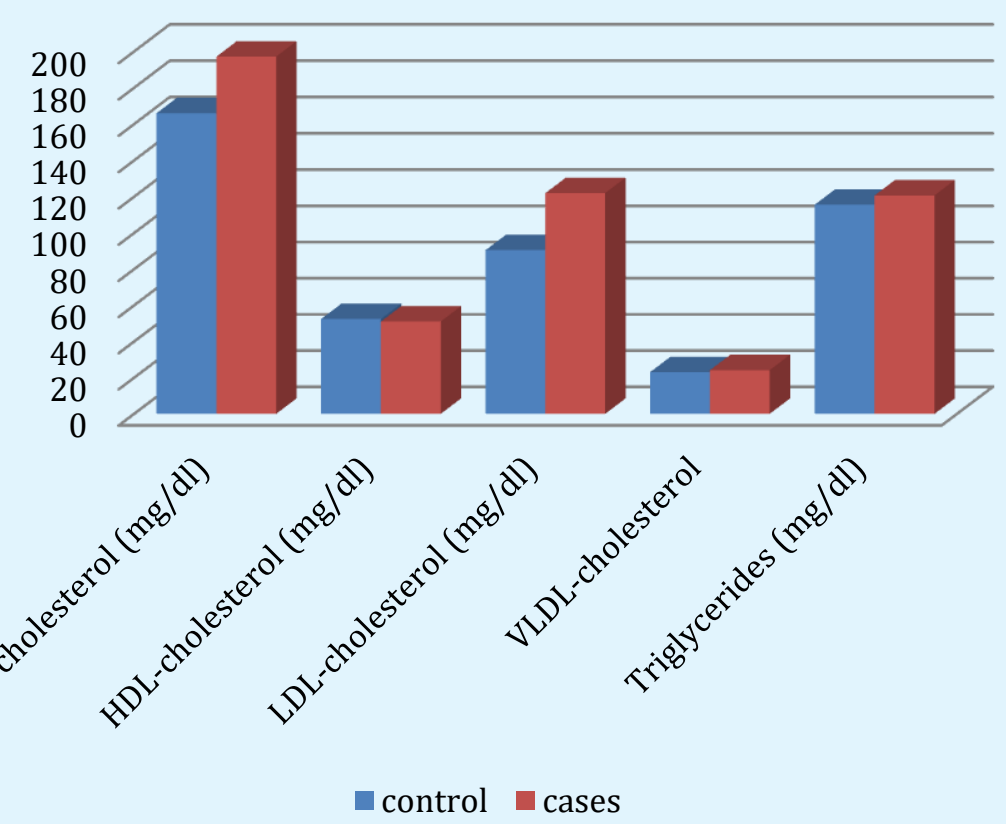

Figure 1: Comparison of total cholesterol, HDL- cholesterol, LDL- cholesterol, VLDL cholesterol, Triglycerides in study groups.

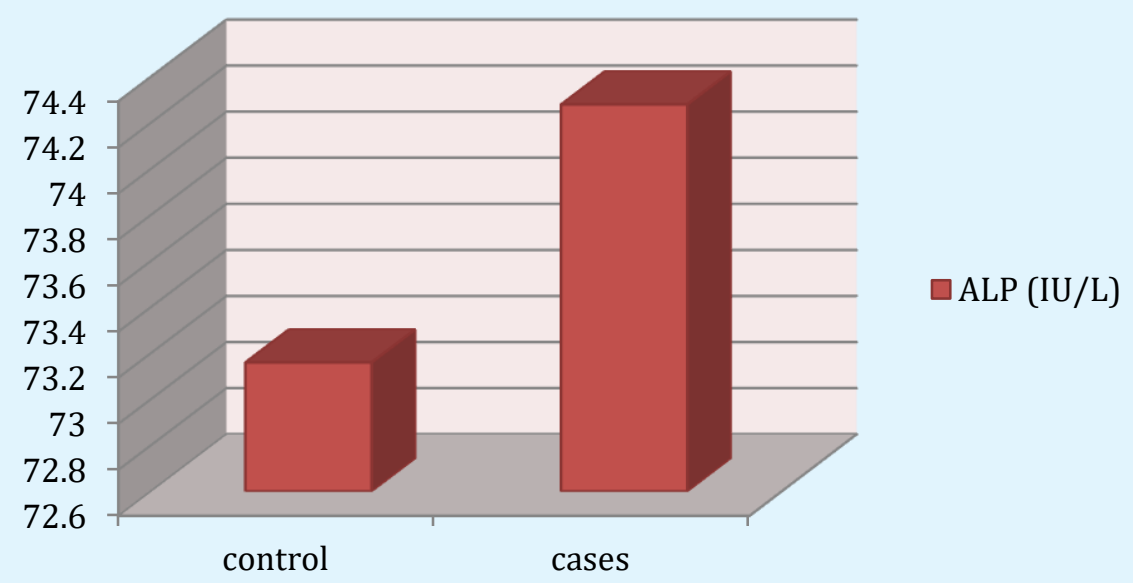

Figure 2: Comparison of Alkaline phosphates (ALP) in study groups

\section{Discussion}

Breast cancer is one of the commonest causes of cancer mortality in females. It is responsible for the death of millions of women worldwide every year. It is a disease which usually begins as a localized proliferation of cells, which over the course of time, spreads to regional lymph nodes and then to distant tissues in the body (bones, liver, lungs, etc.)

In the present study, it was observed that cases had overall higher serum total cholesterol, LDL-cholesterol, 


\section{International Journal of Biochemistry \& Physiology}

triglycerides and VLDL cholesterol levels; and depleted levels of HDL-cholesterol, as compared to controls. Of the total lipid profile parameters, serum total cholesterol and LDL-cholesterol were noticed to be significantly altered in breast carcinoma. Whereas, HDL cholesterol, triglycerides and VLDL-cholesterol exhibited non-significant alteration.

It was observed that the mean of total cholesterol in controls \& cases were $165.96 \pm 25.9 \mathrm{mg} / \mathrm{dl}, 197.14 \pm 36.14$ $\mathrm{mg} / \mathrm{dl}$ respectively. This raised in total cholesterol level among women with breast cancer was highly significant compared to the controls $(\mathrm{p}<0.0001)$ the mean of triglycerides in controls \& cases were $115.54 \pm 27.73$ $\mathrm{mg} / \mathrm{dl}, 120.70 \pm 29.66 \mathrm{mg} / \mathrm{dl}$ respectively. There was no significant difference in Triglycerides between patient and control $(p>0.05)$.

The mean of LDL-cholesterol in controls \& cases were $90.49 \pm 24.53 \mathrm{mg} / \mathrm{dl}$ and $121.97 \pm 36.39 \mathrm{mg} / \mathrm{dl}$ respectively so was significant difference in LDL-Cholesterol concentrations between patient and control $(p>0.0001)$.

The possible mechanisms for these alterations in lipid profile in breast carcinoma may be due to interplay of these lipid metabolisms by cells and influence of female sex steroid hormones on breast tissue physiology. Several methodological aspects may explain the diverse conclusions, but the influence of cholesterol in $\mathrm{BC}$ risk remains to be clinical demonstrated. It has previously been hypothesized that cholesterol plays role in carcinogenesis [4]. Mammary tissue metabolizes lipids from plasma under the influence of gonadal hormones.

Malignant proliferation has been shown to be associated with aberrations in plasma lipids and lipoproteins. The elevated serum LDL-cholesterol, as noticed has been shown to be more susceptible to oxidation, and may result in high lipid peroxidation in breast cancer patients. This may cause oxidative stress leading to cellular and molecular damage, thereby resulting in cell proliferation and malignant conversions, which may be true with breast tissue. The proinflammatory microenvironment induced by highcholesterol levels, as seen in atherosclerosis, in which LDL-C is the most important causative factor $[5,6]$ can also play an effect on breast cancer initiation and progression. The use of statins before cancer diagnosis reduces cancer related mortality [7] reduction of LDL-C is supposed to be the main mechanism through which statins exert effect [8-16].
In the present study we didn't find any significant difference in serum HDL-cholesterol levels among both groups In the present study the mean of serum ALP in controls and cases were $73.16 \pm 10.2 \mathrm{IU} / \mathrm{L}, 74.28 \pm 10.6$ IU/L respectively.

In the present study the mean of serum ALP in controls and cases were 73.16 $\pm 10.2 \mathrm{IU} / \mathrm{L}, 74.28 \pm 10.6$ IU/L respectively. The level of alkaline phosphatase is slightly higher in cases compared to control but there was no significant difference in ALP between patient and control $(p>0.05)$.

As we had excluded stage IV patients from our study, this finding was in accordance with findings reported by Mishra S, et.al. [6] in which they reported that Patients with metastasis had elevated levels of ALP as compared to non metastatic patients. ALP which showed a nonsignificant rise in non-metastatic cases, registered a significant rise of fold in metastatic patients suggesting involvement of bone and liver. Singh A, et al. [17] carried out study on advanced stage of breast cancer hoist alkaline phosphatase activity and reported a significant increase in levels of ALP in stage IV of the disease. Kaur A, et al. [18] also reported significant increase in level of ALP in stage-IV only. Similarly Vanhoof, et al. [19] and Stieber, et al. [20] did not find any significant difference in ALP levels in non-metastatic breast cancer. A significant rise in ALP in metastasis suggests involvement of bone and liver.

\section{Conclusion}

In the present study, the following findings were concluded-

1) Serum total cholesterol and LDL-cholesterol levels were elevated significantly in breast carcinoma cases than control.

2) Serum total cholesterol and LDL-cholesterol might play important role in breast carcinogenesis.

3) Serum alkaline phosphatase didn't vary much in breast cancer cases.

The study showed that breast cancer patients had significantly higher levels of total cholesterol \& LDLcholesterol while insignificant association was found in levels of HDL-cholesterol, VLDL-cholesterol \& triglycerides between cases \& controls. Serum LDH level was found to be significantly higher in breast cancer patients whereas ALP didn't differ significantly. 


\section{International Journal of Biochemistry \& Physiology}

\section{References}

1. Agarwal G, Ramakant P (2008) Breast Cancer Care in India: The Current Scenario and the Challenges for the Future. Breast Care (Basel) 3(1): 21-27.

2. National Cancer Registry Program (2001) Ten year consolidated report of Hospital Based Cancer Registries. An assessment of the burden and care of cancer patients. New Delhi: Indian Council of Medical Research.

3. Wang W, Lei Y, Mei H, Wang L (2015) Recent progress in HER2 associated breast cancer. Asian Pac J Cancer Prev Apjcp 16(7): 2591-2600.

4. Cruz R, Mo H, McConathy J, Sabnis N, Lacko G (2013) The role of cholesterol metabolism and cholesterol transport in carcinogenesis: a review of scientific findings, relevant to future cancer therapeutics. Frontiers in Pharmacol 4: 119.

5. Ross R (1999) Atherosclerosis-an inflammatory disease. New Engl J Med 340(2): 115-126.

6. Buchwald H (1992) Cholesterol inhibition, cancer and chemotherapy. Lancet 339(8802): 1154-1156.

7. Owiredu W, Donkor S, Wiafe B, Amidu N (2009) Serum Lipid Profile of Breast Cancer Patients. Pak J Bio Sci 12(4): 332-338.

8. Llaverias G, Danilo C, Mercier I (2011) Role of Cholesterol in the Development and Progression of Breast Cancer. Ame J Pathol 178(1): 402-412.

9. Rodrigues D, Fonseca I, Dias S, Mendes de Almeida JC (2014) Plasma level of LDL-cholesterol at diagnosis is a predictor factor of breast tumor progression. BMC Cancer 14: 132.

10. Hasija K, Bagga H (2005) Alterations of serum cholesterol and serum lipoprotein in breast cancer of women. Indian J Clin Biochem 20(1): 61-66.

11. DeBerardinis RJ, Lum JJ, Hatzivassiliou G, Thompson CB (2008) The biology of cancer: metabolic reprogramming fuels cell growth and proliferation. Cell Metabol 7(1): 11-20.

12. Clendening JW, Pandyra A, Boutros PC, Ghamrasni S, Khosravi F, et al. (2010) Dysregulation of the mevalonate pathway promotes transformation. Proc Natl Acad Sci USA 107(34): 15051-15056.

13. Ginestier C, Monville F, Wicinski J, Cabaud O, Cervera $\mathrm{N}$, et al. (2012) Mevalonate metabolism regulates Basal breast cancer stem cells and is a potential therapeutic target. Stem cells 30(7): 1327-1337.

14. Hansson GK, Libby P (2006) The immune response in atherosclerosis: a double-edged sword. Nat Rev Immunol 6(7): 508-519.

15. Nielsen SF, Nordestgaard BG, Bojesen SE (2012) Statin use and reduced cancer-related mortality. New Engl J Med 367(19): 1792-1802.

16. Mishra S, Sharma D, Sharma P (2004) Studies of biochemical parameters in breast cancer with and without metastasis. Indian J Clin Biochem 19(1): 7175 .

17. Singh A, Pandey M, Kumar R, Sharma A (2013) Advanced stage of breast cancer hoist alkaline phosphatase activity: risk factor for females in India. Biotech 3(6): 517-520.

18. Kaur A, Mahajan M, Khichy S (2017) Biomarkers of carcinoma breast in females. Int J Recent Scienti Res 6(2): 2625-2629.

19. Vanhoof O, Vanoostrom T, Lepoutre G, Debroe E (1992) Alkaline phosphates isoenzyme patterns in malignancy disease. Clin Chem 38(12): 2546-2551.

20. Stieber P, Mangal D, Ritzke C, Rossler N, Kirsch CM, et al. (1992) Significance of bone alkaline phosphatase, CA15-3 and CEA in detection of bone metastasis during follow up of patients suffering from breast carcinoma. Eur J Clin Chem Clin Biochem 30(12): 809814. 